\title{
REMEDIES FOR THE TRIAL IN ABSENTIA. THE RECENT ROMANIAN EXPERIENCES
}

\author{
Adrian Stan, PhD candidate, Teaching and Research Assistant \\ Faculty of Law, West University of Timișoara \\ Timișoara, Romania, Eroilor Blvd, 9A, Timisoara, 300575 Timis, Romania \\ av.stanadrian@gmail.com; adrian.stan83@e-uvt.ro
}

\begin{abstract}
Accepting the fact that a person can be tried without being personally notified is one of the great concessions that the right to a fair proceeding makes to the public interest and the efectiveness of criminal trial. However, the remedy for such a possibility must be itself effective and it is one of the real challenges of the EU states. This is because sometimes it is very difficult to determine, objectively, whether a person has really been out of criminal proceedings or he is just letting it to be believed.
\end{abstract}

So, we are talking about a series of rights and interests in conflict. As we stated, the celerity of the proceedings, finding the truth, the security of the final decisions, the defense and the fair trial. All these problems are encountered when the issue of the judgment in absentia and its remedies are raised. So, the central goal of our paper is outlining the concept of contumacy and observing the Romanian legal order specificities.

In Romanian procedural system, the trial can be held in absentia, if the accused is not found at the legal or known residence. The prosecutor or the judge must perform reasonable efforts to find the offender, by carrying out investigations in the labor registers, or at the detention places. However, the person still can not be located by the authorities. The summons are communicated, and the procedure is legal even they are not personally received.

As a rule, in Romania, the importance of personal participation in criminal trials is very high. If the defendant is absent and found guilty, the judge has very less posibilities of sentencing without deprivation. The person identified by the police in any state is arrested and the question of his extradition is raised. In which cases Romanian system enables the reopening of the proceedings?

We will try to identify the effectiveness of this remedy in the pre-trial stage, in accordance with those retained by the ECHR (well-known Sejdovic. v. Italy, Colozza v. Italy) but also by the recently CJUE case-law (e.g. Pawel Dworzecki). We will identify the conditions provided by the Romanian law regarding, in particular, the personal summoning. 
We also intend to analyze, briefly, the conclusions of a recent decision of the Romanian Constitutional Court, which requires that, after admitting the request to retrial, the file should resume from the moment of challenging the lawfulness of the investigation, which, in the Romanian system, is prior to the trial of the case.

Keywords: trial in absentia, personal summons, EAW, resumption of trial, preliminary chamber

\section{AVOIDANCE, INDIFFERENCE OR IGNORANCE?}

The old scholars said that "contumax pro convicto et confesso habetur". That means that the contumacy itself was a severe presumption of guilt, because it was accepted that only a culpable defendant avoids presence at his own criminal trial ${ }^{1}$. The fight of modern criminal law with this old dictum is far to be finished. The contemporary legislations try to face with this serious problem: the judgement in absentia and the rights of the person convicted in this special situation.

Whether it was absent from his own trial by avoidance, indifference or ignorance, the status of the convicted in absentia is seriously and certainly unfavorable. $\mathrm{He}$ will be faced, most of the times, if he is found and arrested, with a warrant for the execution of the custodial decision issued after a trial where he did not participate.

On one hand, deciding the destiny of a person without his presence seems to cast a shadow on the principle of fair trial and sometimes on the concept of justice itself. On the other hand, the requirement of personal presence of the accused poses a variety of practical problems, mainly concerning executability and inevitability of the punishment. Nevertheless, the absence of the main actor in a court drama always entails a challenge to the due process of law, and a need for proper remedies to address such a challenge ${ }^{2}$.

The difficulty of the solution in these cases is precisely due to the origin of the contumacy. It is very difficult to assimilate the situation of the one who did not actually know that the authorities initiated a criminal investigation against him with the person who knew it, but avoided the investigation and the procedures. But we can go even further. Can we make reference to his subjective position with the offence that he is supposed to have committed? The answer is difficult.

First, we start from the assumption that a criminal offence was committed, and second that the authorities impute it to a person. It is possible that the subject has

1 Dezza, E., „Il granduca, i filosofi e il codice degli irochesi. Il principio contumax pro confesso habetur e la riforma leopoldina", [https://riviste.unimi.it/index.php/irlh/article/view/12875], accessed on 14. April 2020

2 Augustyniak, B. et al., The concept of "a trial in absentia resulting in a decision" within the European Arrest Warrant framework, [http://www.ejtn.eu/PageFiles/17290/WR\%20TH-2018-01\%20PL.pdf], accessed on 14. April 2020 
the awareness of committing an unlawful act, assuming a possible investigation regarding it. However, he leaves the country or changes his residence, the consequences being unimportant to him.

On the other hand, the person may not have the consciousness of the illicit behaviour, being confident that he did not violate the criminal law, following his dayto-day activities naturally, although the authority initiates a criminal investigation against him. Finally, there is also the possibility that the person can find out about the initiation of criminal proceedings against him and yet he will not attend the hearings or the trial, avoiding them. This last case is usually the one where the right to reopen the procedures is hardly accepted.

Absence from the trial is seen in many situations as a liability sign. In some cases, this statement is real, but it cannot be converted into a presumption. Returning to the previous observations, the missing person is somehow automatically accused of a malicious attitude, of avoiding presence. For this reason, his guilt seems easier to argue for the judge. He does not show up for trial because he is guilty and he assumes a conviction. However, this reasoning is clearly in contradiction with the presumption of innocence that any accused in a criminal trial must benefit.

Even the word contumacy comes from the Latin contumace which has the meaning of "bold, disobedient, unsupported, which does not conform" ${ }^{3}$. Considering this status as a manifestation of contempt for justice or rebellion against authority is one of the old traditions of criminal trial, which only with serious difficulty the contemporary systems are trying to get rid of. ${ }^{4}$ The state had to react more quickly, with a restrictive, severe procedure, with an energic judgment. Some more radical views considered the contumacy itself as a distinct crime. ${ }^{5}$

However, even in the modern period, some very interesting opinions were exposed. In a report of the Italian Parliamentary Commission for the revision of the Criminal Procedure Code of 1930, it was held in a radical opinion that "the re-judging of the convicted person is an exorbitant protection of the rights of the defendant, thereby favouring his hiding, setting barriers to criminal justice and infinite extensions in the procedure. Often re-judging is a real scandal, a mockery of justice, causing a new trial with diminished or deleted evidence, with excessive

According to Cambridge dictionary, contumacy means „refusing to obey or respect the law in a way that shows contempt, [https://dictionary.cambridge.org/dictionary/english/contumacious], accessed on 14. April 2020

4 Pop, T.,Drept procesual penal, vol. IV, Tipografia Naţională Cluj, 1948, pp. 320-321

5 Karas, E. I., Reopening of proceedings in cases of trial in absentia: European legal Standards and Croatian law, in: Duić, D.; Petrašević, T. (eds.), EU and comparative law issues and challenges series, vol. II, 2018, [https://hrcak.srce.hr/ojs/index.php/eclic/article/view/7113/4604], accessed on 14. April 2020 
indulgence of judges, because too much time has elapsed since the crime was committed and repression is no longer necessary". ${ }^{6}$

It is a requirement of any legal system to decide its cases quickly. Very important issues are involved in this necessity. First, punishments must be applied close to the time of the commission of the crime for which the punishment is administered. If the punishment serves any purpose (deterrence, rehabilitation or retribution), it makes no sense to postpone its application without a reason. The sooner it is applied, the more efficient it becomes. Second, the trial, which is the only legal way to apply a punishment, would not function properly if the cases are decided long after the criminal conduct. Witnesses tend to forget about past actions, some of them move out of the city, and records get lost. In sum, it becomes more difficult for both the government and the defendant to collect evidence. Finally, if society has a legitimate interest in the resolution of criminal cases, it is obvious that a delay in trial and punishment does not help to fortify the confidence of the people in the judicial system. One way to avoid these negative consequences is a trial in absentia because it helps to prevent the defendants from manipulating the judicial system by deciding with their presence whether or not a case can by tried. ${ }^{7}$

\section{A BRIEF OF THE ECTHR LEADING CASE-LAW}

There are many international Courts that accept procedures in absentia. Maybe the most disputed are the international criminal Tribunals, but it is not our goal to analyse them. ${ }^{8}$ The Court of Strasbourg, applying the Convention, ruled a series of cases in the field starting with the 80's of the last century. ${ }^{9}$ Even if the member states have successfully succeeded in aligning a great part of their law to extend and clarify this procedure, the decisions, even if rarer, are not totally extinct. ${ }^{10}$ The so-called "leading case" is Colozza vs Italy. ${ }^{11}$

6 Manzini, V., Tratatto di diritto procesuale penale italiano, Torino, 1931-1932, vol. IV, p. 400

7 Tassara, L., Trial in absentia: rescuing the "public necessity" requirement to proceed with a trial in the defendant's absence, Barry Law review, vol. 12, Issue 1 Spring 2009, [https://lawpublications.barry.edu/ cgi/viewcontent.cgi?article=1073\&context=barrylrev], accessed on 14. April 2020

8 Zakerhossein, M.H.; De Brouwer A-M., Diverse approaches to total and partial in absentia trials by international criminal tribunals, Criminal Law Forum, 2015, [https://link.springer.com/content/ pdf/10.1007/s10609-015-9257-0.pdf], accessed on 14. April 2020

9 Bârsan, C., The European Convention of Human Rights, Commens by articles, 2nd Ed., CH Beck, Bucharest, 2010, p. 499; Chiriță, R., The European Convention of Human Rights, Comments and explanations, CH Beck, Bucharest, 2008, p. 337

10 The case was summarized from the official page of the Strassbourg Court, [https://hudoc.echr.coe.int/ eng\#\{“documentcollectionid2":[“GRANDCHAMBER”,"CHAMBER”]\}], accessed on 14. April 2020

11 ECHR, Colozza v. Italy, App. 9024/80, judgment of 12 February 1985 
Mr. Giacinto Colozza was born in 1924 and died in 1983 in prison, during the proceedings. We can say he did not survive to see his success in the Court. He was an Italian citizen and lived in Rome.

On 4 October 1973, the investigating judge issued a "judicial notification" intended to inform him of the opening of criminal proceedings against him. A bailiff attempted to serve it on Mr. Colozza at the address shown in the official records, but without success: he had moved and had omitted to inform the City Hall of his change of residence as required by law.

On 14 November 1973, after unsuccessful searches at the address, the investigating judge declared the accused untraceable (irreperribile), appointed an official defence lawyer for him and continued the investigations. Thereafter, in pursuance the Code of Criminal Procedure, all the documents which had to be served on the applicant were lodged in the registry of the investigating judge, the defence counsel being informed in each case.

On 20 May 1977, the public prosecutor's office issued an arrest warrant. Colozza was arrested at his home in Rome (at other adress than the official one). On the next day, he raised a "procedural objection" as regards this warrant and at the same time filed a "late appeal"

On 29 April 1978, the Rome Regional Court dismissed the "procedural objection" and ordered that the papers be sent to the Rome Court of Appeal for a ruling on the "late appeal".

Mr. Colozza maintained that he had been wrongly declared "latitante" and that the notifications of the summons to appear and of the extract from the judgment rendered by default were therefore null and void.

He explained that, as he had received notice to quit from his landlord at the end of 1971, he had left his flat in Via Fonteiana and, before finding a new one, had lived in a hotel. He pointed out that his new address (via Pian Due Torri) was known to the police since, on 12 March 1977, they had summoned him to the local police station for questioning; the same applied both to the Rome public prosecutor's office, which, on 7 October 1976 (that is to say, almost two months before adoption of the judgment), had sent him a "judicial notification" concerning other criminal proceedings, and to various public authorities, which had served documents on him, using the notification service of the Rome City Hall.

Court of Cassation finally dismissed his demands, it considered that Mr. Colozza had rightly been declared first to be "irreperibile" and then to be a "latitante". 
The European Court recalled that the guarantees contained in paragraph 3 of Article 6 are constituent elements, amongst others, of the general notion of a "fair trial". In the circumstances of the case, the Court, whilst also having regard to those guarantees, considers that it should examine the complaint under paragraph 1, which provides: "In the determination of ... any criminal charge against him, everyone is entitled to a fair ... hearing ... by [a] ... tribunal ... ."

The basic question is whether the combined recourse to the procedure for notifying persons who are untraceable (irreperibile) and to the procedure for holding a trial by default - in the form applicable to "latitanti", deprived Mr. Colozza of the right at a fair trial.

The Court said that although this is not expressly mentioned in paragraph 1 of $\mathrm{Ar}$ ticle 6 , the object and purpose of the 6 Article taken as a whole show that a person "charged with a criminal offence" is entitled to take part in the hearing. Moreover, sub-paragraphs (c), (d) and (e) of paragraph 3 guarantee to "everyone charged with a criminal offence" the right "to defend himself in person", "to examine or have examined witnesses" and "to have the free assistance of an interpreter if he cannot understand or speak the language used in court", and it is difficult to see how he could exercise these rights without being present.

In this case, the Court does not have to determine whether and under what conditions an accused can waive exercise of his right to appear at the hearing since in any event, according to the Court's established case-law, waiver of the exercise of a right guaranteed by the Convention must be established in an unequivocal way.

In fact, the Court is not here concerned with an accused who had been notified in person and who, having thus been made aware of the reasons for the charge, had expressly waived exercise of his right to appear and to defend himself. The Italian authorities, relying on no more than a presumption inferred from the status of "latitante" which they attributed to Mr. Colozza that there had been such a waiver.

In the Court's view, this presumption did not provide a sufficient basis. Examination of the facts does not disclose that the applicant had any inkling of the opening of criminal proceedings against him. It is difficult to reconcile the situation found by the Court with the diligence which the Contracting States must exercise in order to ensure that the rights guaranteed by Article 6 are enjoyed in an effective manner.

In conclusion, the material before the Court did not disclose that Mr. Colozza waived exercise of his right to appear and to defend himself or that he was seeking to evade justice. It is therefore not necessary to decide whether a person accused of 
a criminal offence who does actually abscond thereby forfeits the benefit of the rights in question.

It is not the Court's function to elaborate a general theory in this area. The impossibility of holding a trial by default may paralyse the conduct of criminal proceedings, in that it may lead, for example, to dispersal of the evidence, expiry of the time-limit for prosecution or a miscarriage of justice. However, in the circumstances of the case, this fact does not appear to the Court to be of such a nature as to justify a complete and irreparable loss of the entitlement to take part in the hearing. When domestic law permits a trial to be held notwithstanding the absence of a person "charged with a criminal offence" who is in Mr. Colozza's position, that person should, once he becomes aware of the proceedings, be able to obtain, from a court which has heard him, a fresh determination of the merits of the charge. Obviuosly, the Court concluded that there was a violation of Article 6 para.1.

\section{CJEU AND THE EUROPEAN ARREST WARRANT}

Court of Justice of the European Union held many recent decisions that regard the execution of European Arrest Warrant (EAW) involving a previous in absentia trial. It is not our goal to analyse this problem, but the specialists observed it in many scientific works. ${ }^{12}$

The most discussed is the Melloni case ${ }^{13}$. In judgment Melloni ${ }^{14}$, using literal interpretation, the CJEU specified that Article $4 \mathrm{a}(1)$ of Framework Decision 2002/584/JHA provides for a trial in absentia as an optional ground for the nonexecution of the EAW, which, though, is "accompanied by four exceptions in which the executing judicial authority may not refuse to execute the European arrest warrant in question."

In this specific case, difficulties in the implementation of succesive EU Framework decisions became visible. Practice on EAW made clear that for a better international cooperation, more harmonization and equivalent minimum standards

12 For details, Karas, E. I., Decisions rendered in absentia as a ground to refuse the execution of a european arrest warrant: European legal standards and implementation in Croatian law, [https://www.pravo.unizg. hr/_download/repository/1._Ivicevic_Karas-Decisions_rendered_in_absentia.pdf], accessed on 14 . April 2020

13 Schneider, A., In absentia trials and transborder criminal procedures. The perspective of EU Law, in Quattrocolo, S.; Ruggeri, S. (eds.), A Comparative Study of Participatory Safeguards and in absentia Trials in Europe, Springer, 2019, p. 605 et seq.

14 CJEU, (Grand Chamber) C-399/11 Stefano Melloni v. Ministerio Fiscal, 26 February 2013, par. 41 
should be fostered. ${ }^{15} \mathrm{Mr}$ Melloni was informed of the trial and he was represented and effectively defended by two counsels that he appointed. These two guarantees alone were sufficient to eliminate the option to refuse the execution of the EAW. The CJEU clarified that this actually precluded any additional surrender condition, including the conviction rendered in absentia to be open to review in the issuing member state, in the presence of the convicted person In other words, the CJEU actually specified that the list of grounds allowing the refusal of the execution of the EAW for Article $4 \mathrm{a}(1)$ is exhaustive, and the four guarantees are listed alternatively and not cumulatively. Yet, such reasoning is disputable from the perspective of the jurisprudence of the ECtHR. Therefore, the scope of human rights protection in the execution of an EAW, in cases of trials in absentia, does not seem to fully comply with the guarantees provided in the jurisprudence of the ECtHR. ${ }^{16}$

Returning to the Romanian procedure, the CCP (Code of Criminal Procedure) speaks only of "legal summoning", and not about "personal summoning". Although, the Courts accept, applying the CJEU cases, that when the notification is not personal, the defendant has the right to have the case re-openned. One of the most recent recalled cases is judgement C108/16 PPU (Paweł Dworzecki) ${ }^{17}$, where the Luxembourg Court stated that:

"Article 4a(1)(a)(i) of Council Framework Directive 2002/584/JHA of 13 February 2002 on the European arrest warrant and the surrender procedures between Member States, as amended by Council Framework Decision 2009/299/JHA of 26 February 2009, must be interpreted as meaning that the expressions 'summoned in person' and 'by other means actually received official information of the scheduled date and place of that trial in such a manner that it was unequivocally established that he or she was aware of the scheduled trial' in that provision constitute autonomous concepts of EU law and must be interpreted uniformly throughout the European Union.”

„Article 4a(1)(a)(i) of Framework Decision 2002/584, as amended by Framework Decision 2009/299, must be interpreted as meaning that a summons, such as that at issue in the main proceedings, which was not served directly on the person concerned but was handed over, at the latter's address, to an adult belonging to

15 Bachmayer Winter, L., New Developments in EU Law in the field of In Absentia national proceedings. The Directive 2016/343/EU in the light of the EctHR Case Law, in Quattrocolo, S.; Ruggeri, S. (eds.), A Comparative Study of Participatory Safeguards and in absentia Trials in Europe, Springer, 2019, p. 641 et seq.

16 Karas, op.cit. note 12, p. 464

17 CJEU, C-108/16 PPU Pawel Dworzecki, 24 May 2016 
that household who undertook to pass it on to him, when it cannot be ascertained from the European arrest warrant whether and, if so, when that adult actually passed that summons on to the person concerned, does not in itself satisfy the conditions set out in that provision."

\section{REOPENING A CRIMINAL CASE ACCORDING TO THE NEW ROMANIAN CRIMINAL CODE OF PROCEDURE. SOME CONTROVERSIES}

The dispositions of the former Romanian CCP (1969) provided for the possibility to reopen criminal cases only related to persons extradited in Romania ${ }^{18}$. Noting the limited access to this procedure related to the non-extradited persons or to other incarcerated individuals, but also the ECtHR decisions, which set that the presence of the person to the trial relates to the essence of its fair character, the new CCP effective in 2014 reset and extended the procedure.

Romanian Constitution does not contain express provisions in the matter ${ }^{19}$. The fundamental law states that "the jurisdiction of courts and the rules of proceedings are regulated only by the law". This statement should not imply that the Romanian legal system completely disregards the presence of the parties at the trial, since the same fundamental act states the pre-eminence of international documents and treaties on fundamental human rights. These are directly applicable in Romanian legislation.

Therefore, any person judged in absentia shall be entitled to the reanalyzing of the cause in case of cumulative fulfilment of several conditions provided for by the procedural code (art. $466 \mathrm{CCP})$ :

\subsection{The request has to be lodged in the one month term starting from the day the convicted was informed, by any official notification, that a criminal trial was held against him.}

The individual convicted in absentia is usually informed about the criminal trial against him in the moment of the incarceration. But this happenes only if the person is located. Sometimes, assuming that the defendant was not located during the criminal investigations or trial, it is difficult to believe that he will be later, in the execution proceedings.

18 Ciopec, F, Retrial in case of extradition, Ann Fac Law Timișoara, no. 1/2006, pp. 162-168

19 Ciopec, F.; Roibu, M., Report on Romania, in: Quattrocolo, S.; Ruggeri, S. (eds.), A Comparative Study of Participatory Safeguards and in absentia Trials in Europe, Springer, 2019, p. 361 et seq. 
But does the one-month term begin when the person is not found yet? There are convicts that do not live anymore in the state that held the trial against them. Furthermore, the official communication of the documents or the warrant were not fulfilled by the Romanian authorities. Is this an impediment regarding the admissibility of their request? The dominant opinion is negative. Thus, art. 466 paragraph. 3 CCP refers to the communication after bringing the person into the country. Certainly, its interpretation in the sense that the persons who are not in the country could not draft the claim for retrial would restrict their free access to justice.

Therefore, the request made just before the start of the one-month term provided by law is admissible and not premature. The one-month term is only a maximum, established in benefit of the convicted, precisely because the situation of those for whom extradition is requested is one of increased vulnerability ${ }^{20}$.

\subsection{The person has not been legally summoned and has not been informed officially about the criminal proceedings against him}

Related to the negative condition for the person to have not been legally summoned, the simple existence of a summoning or the notice of the decision is pure judicial fiction, created by the legislator aiming not to block the activity of courts. As we observed, even ECtHR and CJEU accept the trial in absentia. Therefore, it is allowed to trial the accused, even if they are absent from the proceedings and their address is unknown.

Some interpretation dilemmas appeared in Romanian practice. The dominant solution is that the summoning of the defendant in accordance with the legal provisions in force at the time the trial was held should not lead to the conclusion that the accused avoided the proceedings or, even worse, that he knew about the trial. ${ }^{21}$ The same author observes that the Romanian standard is somehow superior than the European Convention, because the international document does not exclude the possibility that, in the absence of an official notification, "certain established facts might provide an unequivocal indication that the accused is aware of the existing criminal proceedings against him and he does not intend to take part in the trial".

In most of the criminal cases requested for reopening, the summoning procedure was legal, summons being communicated to an old residence of the individual,

\footnotetext{
20 Udroiu, M., Criminal procedure. General part, 6 th edn. CH Beck Publishing House, Bucharest, 2019, p. 736

$21 \quad$ Ciopec; Roibu, op. cit. note 19, p. 397
} 
or displayed at the prosecutor's office or local council. Despite all this, personal notice is missing, because it can only be signed by the accused itself. ${ }^{22}$

Romanian Courts decided in a specific case that ${ }^{23}$ "the decision was communicated to the defendant at the same address and also returned with the mention that "she moved to UK" It should be noted that the defendant was not heard during the criminal investigation, the search documents proving that she moved to Italy and UK (...), respectively, there being practically no official notification to the defendant from which she would be informed that a criminal trial exists against her.

The defendant was never informed of the existence of a criminal charge against her, and the summons to the address with which it appears in the DEPABD (the official Police database), given that he had lived in UK for several years, is not equivalent to the summons "to the address where he lives", according to art. 259 paragraph 1 CCP.

For this reason, the Court cannot agree with the argument put forward by the first instance tribunal, which considered that the defendant knew about the trial because she was summoned to her home on (...) on 28.02.2013, the summons being received by D., relative to the defendant, and on 22.01.2014 the summons was received by $M$, the addressee's brother-in-law, as this "procedure" cannot constitute an official notification, within the meaning of art. 466 al. 2 CCP, which refers to the summonning procedure before the court and not to the criminal investigation phase.

The Court finds that in this way the convicted person was not legally summoned for the trial and did not become aware of it in any other official way, so that the conditions provided by law to be considered an in absentia convicted person are met."

\subsection{The defendant has not appointed a lawyer and has not asked for the judgment in absentia}

It is obvious that the person appointing a lawyer/counsel is aware that certain criminal procedures are held against him. In specific cases where a lawyer was appointed, the convicted in absentia tries to prove that the lawyer was appointed by the family, without his knowledge. These arguments are usually analyzed in concreto from one case to another, but almost all of them are rejected by the courts, as it is real difficult to assume reasonably that a family member appoints a lawyer

22 Iugan, A.V., Retrial of the the criminal case, Universul Juridic Publishing House, Bucharest, 2016
23 Bacău Court of Appeal, Decision no. 1357 of 21.11.2018, [www.rolii.ro], accessed on 14 April 2020 
without informing the person concerned regarding the criminal investigation or trial.

In Sulejmani v. Albania ${ }^{24}$ the Court stated that when an accused appointed lawyers to represent him in court, "the fact that lawyers were later replaced by lawyers appointed by members of his family does not alter the clear finding that he knew about the criminal proceedings against him."

Sometimes, during the investigation stage or the trial, the assistance being compulsory, the prosecutor or the court appoints a lawyer ex officio, but his presence do not replace the right of the accused person to defend himself, the legal negative condition only relating to the lawyer appointed by the suspect.

\subsection{The request for reopening cannot be lodged by the person who has not filed an appeal after the legal receiving of the conviction decision}

This condition needs to be analysed in mirror with that of the personal summoning, meaning that the decision, in order to be legally remedied by an appeal, needs to be personally received.

The meaning of the phrase "after notice, according to law" (art. 466 para. 2 CCP) is not that of a notice legally performed based on the presumptions provided for by the law (as leaving the decision in the postal box). Furthermore, the decision is legally received if the papers were signed by persons living with the defendant, but they are not personal received.

The ECtHR judgment in Somogyi v. Italy ${ }^{25}$ is particularly relevant in this respect. In this case, the Court rejected the Italian State's argument that the applicant could have appealed over time, considering that the domestic provisions did not contain sufficient guarantees. The Court also stated that it was not clear whether the petitioner could have actually benefited from a late (over time) appeal and that he had not been obliged to prove that he had not deliberately refused to acknowledge the existence of the process. It was also considered that he could not have effectively exercised this ordinary remedy which could be formulated within 10 days from the date on which the person learned of the trial and that this short period, also related to the fact that he was in a foreign country, it is not likely to satisfy the requirements of the Convention in the light of art. 6.

\footnotetext{
24 ECtHR, Sulejmani v. Albania, decision of 19 june 2012, App. No. 16114/10, para. 22

25 ECtHR, Somogyi v. Italy, decision of 18 may 2004, App. No. 67972/01
} 
The convicted person who did not give any statement in the case and was not aware of it seeks the retrial of the whole trial, and not only of the appeal, with the risk of rejecting it as late or as unfounded. Only retrial starting with the first instance (or, as recent in Romanian procedure, from the moment of preliminary chamber) is the concrete and effective remedy of in absentia trial.

The request to reopen the criminal proceedings is not a subsidiary one to the appeal, as could be assessed, because, if this opinion were accepted, in all cases where an appeal is filed, a subsequent request for reopening would be ab initio stopped, because an appellant obviously knows of the criminal proceedings against him.

Thus, if we admit that the person tried in absentia, completely being out of criminal proceedings, who although legally summoned to a place where he no longer lived and also where his decision was communicated, should file an appeal, practically the institution of reopening the trial would be completely annihilated. A possible appeal over time would not be a sufficient remedy for that judgment.

\section{THE NEW POSSIBILITY TO CHALLENGE THE EVIDENCE IN THE RETRIAL PROCEDURE}

Once the request for reopening the case has been admitted, after the judge analyses the conditions abovementioned, the criminal trial will resume its course, with the observance of the right to a fair trial, by the possibility of insuring the presence of the defendant. The presumption of innocence gets it strength again and the execution warrant is cancelled.

The trial, regarding the law dispositions, has to be reopened from the first moment of first degree trial, which involves the brief presentation of the facts he is accused of. But after 2014, the criminal procedure involves a new stage, situated after the prosecutor finishes the investigation but before the judge opens the first degree triall $^{26}$. The so-called "preliminary chamber", has the aim of a filter the judge applies on the legality of the evidences and documents of the prosecutor from the investigation. ${ }^{27}$

26 Kuglay, I, Preliminary chamber, in Udroiu, M. (ed.), Criminal procedure code. Comments by articles, CH Beck Publishing House, Bucharest, 2017, p. 1413 et seq.

27 According to the CCP (art. 54) the preliminary chamber procedure has the aim to verify if the indictment was legally drawn up by the prosecutor and to verify if the evidence in the file and the investigation activities were lawfully supplied. This special procedure exists in German criminal system and also in Italian legislation (udienza preliminare), see also Cassiba. F., L'udienza preliminare. Struttura e funzioni, Giuffré editore, 2007 
International doctrine pointed that according to Art. 2 of the Directive 2016/34328, the provision applies only to trials which "can result in a decision of guilt or innocence of a suspect or accused person". It is unclear if the right to be present is focused at the court main hearing or it extends to other stages of the proceedings., due to different concepts used in languages of the Directive (e.g. Hauptverhandlung, processo, juicio). ${ }^{29}$

The "preliminary chamber" has been envisaged in Romanian system as an intermediate procedure, situated between the investigation and the judgement stage. First, the procedure was held in camera, but, after several decisions of the Constitutional Court from 2015, the absence of the parties was sanctioned as unconstitutional. ${ }^{30}$ The preliminary chamber does not finish with a guilt or innocence decision (even this possibility exists in other legislations, in Romanian procedure if the judge observes some evidence being unlawfully supplied, he will remove them from the file, or send back the file to the prosecutor). So, this stage will finish only with a decision that certifies the evidence and the investigation were lawfully ordered, or contrary.

So, the preliminary chamber is not a "trial" in its common sense, but a specific "pre-trial", with clear procedure rules and special solutions.

Being asked regarding the moment the trial has to reopen, after the request for retrial is accepted, the Romanian Supreme Court decided in $2017^{31}$ that „in the unitary interpretation and application of the provisions of art. 469 para. (3) of the Code of Criminal Procedure, following the admission of the request for reopening the criminal proceedings for convicted persons tried in absentia, the case is resumed from the trial phase in the first instance."

But after this decision, the norm in the Romanian Constitution related to the equality before law (art. 16 para. 1) is infringed, as the re-judgment without analyzing the legality of the investigation (specific in the preliminary chamber stage) leads to unfairness, differentiating the citizens depending on their presence in court.

28 "This Directive applies to natural persons who are suspects or accused persons in criminal proceedings. It applies at all stages of the criminal proceedings, from the moment when a person is suspected or accused of having committed a criminal offence, or an alleged criminal offence, until the decision on the final determination of whether that person has committed the criminal offence concerned has become definitive."

29 Bachmayer Winter, op..cit. note 15 , p. 652

30 Ciopec; Roibu, op. cit. note 19, p. 381

31 High Court of Justice, Decision 13 of 3 july 2017, Official Journal no. 735 of 13 september 2017 
The situation related to the inequality appears when, by hypothesis, regarding the person judged in absentia who obtains the right to re-trial, the stage of analyzing the lawfulness of the evidence, or of the prosecuting documents is considered definitively stated, despite the fact that the person has not been present in this stage and did not personally receive the summons, in order to express his position.

The situation of the person related to whom the reopening of a trial was admitted should be the same with that of any person brought in court, which is the attendance to the procedural stage - the "preliminary chamber" filter. The equality in front of the law is infringed by the failure to reinstate the person in the situation following procedurally to the notification of the court with the indictment.

In its case law, the Constitutional Court of Romania reiterated the principle that the equality of citizens does not mean uniformity. The infringement of the principle of equality and non-discrimination only exists when a differentiated treatment is applied to equal cases, without an objective and reasonable motivation or if there is a disproportion between the purpose pursued by the unequal treatment and used means. In the criticized case, the latter conditions are totally fulfilled, there being no elements to justify a differentiated treatment.

Therefore, as related to the possibility that unlawfully obtained evidence can be used against a defendant after the retrial is accepted, or void documents may remain effective, the judge of the merits of the case is not able to censor them. So, the different legal treatment is obvious.

Accepting this brief arguments, in a very recent decision, Romanian Constitutional Court stated ${ }^{32}$ contrary to the dictum of the Supreme Court, reversing its effects. The Court stated that: "the provisions of art. 469 para. (3) of the Code of Criminal Procedure, in the interpretation given by Decision no. 13 of July 3, 2017, pronounced by the High Court of Cassation and Justice - regarding the procedural phase from which the criminal process is resumed, are unconstitutional."

Court noted that "Regarding the importance of ensuring the right to challenge evidence in criminal proceedings, the Court held that obtaining evidence legally is a guarantee of the right to a fair trial, and the remedy against non-compliance with this guarantee is to prohibit the use of evidence thus obtained. Moreover, art. 102 para. (2) of the CCP provides that evidence obtained illegally may not be used in criminal proceedings. It was also found that legally obtaining evidence, a guarantee of the right to a fair trial, is a more favorable standard for the citizen

32 Decision no. 590/2019, Official Journal no. 1019 of 18 december 2019 
than the one set by the jurisprudence of the European Court of Human Rights regarding illegally obtained evidence.

According to this jurisprudence, it is noted that the analysis of the European Court of Human Rights aims at the fairness of the procedure as a whole, which also includes the analysis of the way in which the evidence was obtained, since art. Article 6 of the Convention does not lay down rules on the admissibility of evidence, which is primarily a matter of national law, so that the Court's task is not to determine whether certain evidence has been obtained unlawfully, but to determine whether such evidence has been obtained. Curt refered to Judgment of 11 July 2006 in Jalloh v. Germany, para. 94 et seq., Judgment of 5 February 2008 in Ramanauskas v. Lithuania, para. 52 and the following, or the Judgment of 17 December 2013 in Szilagyi v. Romania, paragraph 26 et seq.

In view of these arguments, the Court notes that the retrial of the case from the stage in the first instance, after accepting the reopening of criminal proceedings, according to art. 469 of the CCP, as stated by Decision no. 13 of July 3, 2017 pronounced by the High Court of Cassation and Justice, and not from the preliminary chamber stage, in the event that the defendant was not legally summoned in the aforementioned procedural stage or, although he had knowledge of the trial, was justifiably absent from the trial of the case, violates the right to a fair trial and the right to defense of the person in the analyzed hypothesis, who was convicted in absentia.

Furthermore, for the reasons set out above, the Court notes that the provisions of art. 469 para. (3) of the CCP, in the interpretation given by Decision no. 13 of July 3, 2017 pronounced by the High Court of Cassation and Justice, creates discrimination between persons tried in absentia, in respect of which it is ordered the reopening of the criminal process, according to art. 469 of the Code of Criminal Procedure, but which were not legally summoned and, therefore, did not have the opportunity to participate in the preliminary chamber procedure, and those who participate in all stages of criminal proceedings.

In this regard, the Court notes that the two categories of persons abovementioned are in similar situations, but only persons in the second category have the real possibility to challenge the lawfulness of the evidence drawn by the prosecutor.

In terms of ensuring equality in rights, the Constitutional Court held, by Decision no. 512 of November $18,2004^{33}$ that discrimination is the result of a different legal treatment applicable to the same category of subjects of law or to situations

33 Published in the Official Journal, Part I, no. 1246 of December 23, 2004 
that do not differ objectively and reasonably. Also, by a constant jurisprudence ${ }^{34}$, the Constitutional Court ruled that the principle of equality implies the establishment of equal treatment for situations that, depending on the purpose pursued, are not different. That is why it does not exclude, but, on the contrary, presupposes different solutions for different situations. Consequently, a different treatment cannot only be the expression of the exclusive appreciation of the legislator, but must be rationally justified, respecting the principle of equality of citizens before the law and public authorities. At the same time, by Decision no. 270 of April $23,2015^{35}$, the Court found that a difference in legal treatment is discriminatory when it is not objectively and reasonably justified, meaning that it does not pursue a legitimate aim or does not maintain a reasonable relationship of proportionality between the means used and the intended purpose.

However, in the light of the case-law previously relied on, there are no objective and rational criteria justifying the difference in legal treatment between the categories of defendants analyzed, as regards ensuring the right to be present at the preliminary chamber procedure and to submit procedural objections, according to art. 342 of CCP.

So, after the moment this abovementioned decision was published in Official Journal, the procedure of retrial the convicted in absentia radically changes. After the judge accepts the request, he has to offer the right to challenge the evidence obtained by the prosecutor in absentia, in the preliminary chamber, and only after this filter is finished the stricto sensu retrial can begin.

\section{CONCLUDING REMARKS}

Since the landmark decision in Colozza, hardly accepted by the member states, the participatory rights for the persons convicted in absentia are nowadays recognized in most of the criminal systems, if different certain filter-criteria are fulfilled. Instead of being a reducing phenomenon, in absentia trials are more and more frequent all over Europe.

But the difficulty of the solution in these cases is precisely due to the origin of the contumacy and the sensible line between the duty to take part at the trial or the

\footnotetext{
34 Decision of the Plenum of the Constitutional Court no. 1 of February 8, 1994, published in the Official Journal, Part I, no. 69 of March 16, 1994, Decision no. 540 of July 12, 2016, published in the Official Journal, Part I, no. 841 of October 24, 2016, paragraph 21, Decision no. 2 of January 17, 2017, published in the Official Journal, Part I, no. 324 of May 5, 2017, paragraph 22, and Decision no. 18 of January 17, 2017, published in the Official Journal, Part I, no. 312 of May 2, 2017, paragraph 22

35 published in the Official Journal, Part I, no. 420 of 12 June 2015, paragraph 25
} 
option to act so. It is obvious that it is difficult to assimilate the situation of the one who did not actually know that the authorities initiated a criminal investigation against him with the one who knew it, but avoided the investigation and the procedures. This is why the states provide some filter criteria for the retrial procedure, which, in some cases, are very difficult to fulfil.

Romania adopted this procedure only in 2014, when the new Criminal Code of Procedure was enforced. The "reopening of the criminal trial" is an extraordinary remedy that has the aim not to challenge the unlawful decision ruled in absentia, but to give effectiveness to the right to participate in the proceedings and the right to personal defence. After some practical controversies, and observing the sui-generis stage of the preliminary chamber, the Constitutional Court accepted recently that the convicted in absentia has not only the right to retrial, but also to challenge the lawfulness of the evidence the prosecutor performed against him.

\section{REFERENCES}

\section{BOOKS, ARTICLES, WEB SOURCES}

1. Bachmayer Winter, L., New Developments in EU Law in the field of In Absentia national proceedings. The Directive 2016/343/EU in the light of the EctHR Case Law, in: Quattrocolo, S.; Ruggeri, S. (eds.), A Comparative Study of Participatory Safeguards and in absentia Trials in Europe, Springer, 2019

2. Bârsan, C., The European Convention of Human Rights, Commens by articles, 2nd Ed., CH Beck, Bucharest, 2010

3. Cassiba. F., L'udienza preliminare. Struttura e funzioni, Giuffré editore, 2007

4. Chiriță, R., The European Convention of Human Rights, Comments and explanations, $\mathrm{CH}$ Beck, Bucharest, 2008

5. Ciopec, F, Retrial in case of extradition, Ann Fac Law Timișoara, no. 1/2006

6. Ciopec, F., Roibu, M., Report on Romania, in: Quattrocolo, S.; Ruggeri, S. (eds.), A Comparative Study of Participatory Safeguards and in absentia Trials in Europe, Springer, 2019

7. Iugan, A.V., Retrial of the the criminal case, Universul Juridic Publishing House, Bucharest, 2016

8. Kuglay, I, Preliminary chamber, in: Udroiu, M. (ed.), Criminal procedure code. Comments by articles, $\mathrm{CH}$ Beck Publishing House, Bucharest, 2017

9. Manzini, V., Tratatto di diritto procesuale penale italiano, Torino, 1931-1932, vol. IV

10. Pop, T.,Drept procesual penal, vol. IV, Tipografia Națională Cluj, 1948

11. Schneider, A., In absentia trials and transborder criminal procedures. The perspective of $E U$ Law, in: Quattrocolo, S.; Ruggeri, S. (eds.), A Comparative Study of Participatory Safeguards and in absentia Trials in Europe, Springer, 2019.

12. Udroiu, M., Criminal procedure. General part, 6 th edn. CH Beck Publishing House, Bucharest, 2019 


\section{COURT OF JUSTICE OF THE EUROPEAN UNION}

1. Case C-399/11 Stefano Melloni v. Ministerio Fiscal [2013]

2. Case C-108/16 PPU Pawel Dworzecki [2016]

\section{DECISIONS OF THE EUROPEAN COURT OF HUMAN RIGHTS}

1. Colloza v. Italy, 9024/80, 12 February 1985

2. Sulejmani v. Albania, 16114/10, 19 June 2012

3. Somogyi v. Italy, 67972/01 18 May 2004

4. Sejdovic v. Italy, GC, 56581/00, 1 March 2006

\section{EU LAW}

1. Directive (EU) 2016/343 of the European Parliament and of the Council of 9 March 2016 on the strengthening of certain aspects of the presumption of innocence and of the right to be present at the trial in criminal proceedings, 2016 OJ L 65

\section{LIST OF NATIONAL REGULATIONS, ACTS AND COURT DECISIONS}

1. Law no. 135/2010 (Criminal Code of Procedure), Off. Journal no. 485 from 15 July 2010

2. High Court of Justice, Decision 13 of 3 july 2017, Official Journal no. 735 of 13 september 2017

3. Bacău Court of Appeal, Decision no. 1357 of 21.11.2018

4. Constitutional Court, Decision no. 590/2019, Official Journal no. 1019 of 18 december 2019

\section{WEBSITE REFERENCES}

1. Augustyniak, B., Gadomska, J., Stępkowska, M., Głuszyk. J., The concept of "a trial in absentia resulting in a decision" within the European Arrest Warrant framework, [http://www. ejtn.eu/PageFiles/17290/WR\%20TH-2018-01\%20PL.pdf], accessed on 14. March 2020

2. Dezza, E., "Il granduca, i filosofi e il codice degli irochesi. Il principio contumax pro confesso habetur e la riforma leopoldina", [https://riviste.unimi.it/index.php/irlh/article/view/12875], accessed on 14. March 2020

3. Karas, E. I., Decisions rendered in absentia as a ground to refuse the execution of a european arrest warrant: European legal standards and implementation in Croatian law, [https://www. pravo.unizg.hr/_download/repository/1._Ivicevic_Karas-Decisions_rendered_in_absentia. pdf], accessed on 14. March 2020

4. Karas, E. I., Reopening of proceedings in cases of trial in absentia: European legal Standards and Croatian law, in Duić, D.; Petrašević, T. (eds), EU and comparative law issues and challenges series, vol. II, 2018, [https://hrcak.srce.hr/ojs/index.php/eclic/article/view/7113/4604], accessed on 14. March 2020

5. Tassara, L., Trial in absentia: rescuing the "public necessity" requirement to proceed with a trial in the defendant's absence, Barry Law review, vol. 12, Issue 1 Spring 2009, [https://lawpub- 
lications.barry.edu/cgi/viewcontent.cgi?article=1073\&context=barrylrev], accessed on 14 . March 2020

6. Zakerhossein, M.H.; De Brouwer A-M., Diverse approaches to total and partial in absentia trials by international criminal tribunals, Criminal Law Forum, 2015, [https://link.springer. com/content/pdf/10.1007/s10609-015-9257-0.pdf], accessed on 14. March 2020 